\title{
Effects of Different Nitrogen Applications on Soil Physical, Chemical Properties and Yield in Maize (Zea mays L.)
}

\author{
Heng Zhong1*, Qiao Wang1*, Xinhua Zhao', Qi Du1, Yue Zhao1, Xiaoguang Wang1, \\ Chunji Jiang1, Shuli Zhao', Minjian Cao', Haiqiu Yu" ${ }^{1 \#, ~ D a w e i ~ W a n g # ~}$ \\ ${ }^{1}$ College of Agronomy, Shenyang Agricultural University, Shenyang, China \\ ${ }^{2}$ Corn Research Institute, Liaoning Academy of Agriculture Science, Shenyang, China \\ Email: " haiqiuyu@163.com, wdawei@vip.126.com
}

Received 3 October 2014; revised 19 October 2014; accepted 20 November 2014

Copyright @ 2014 by authors and Scientific Research Publishing Inc.

This work is licensed under the Creative Commons Attribution International License (CC BY). http://creativecommons.org/licenses/by/4.0/

(c) (i) Open Access

\begin{abstract}
Application of nitrogen ( $\mathrm{N}$ ) fertilizer is one of the most important approaches on improving maize grain yield. However, as is known to all, overuse $\mathbf{N}$ fertilizer not only leads to decline of $\mathrm{N}$ use efficiency and maize yield, but also leads to potential risk to environment pollution. This experiment was conducted to determine the effects of $\mathrm{N}$ fertilizer applications with nine different treatments on soil physical-chemical characters and maize grain yield using hybrid variety Zhengdan 958 in 2011 and 2012. Results indicated that the soil bulk densities of $T_{2}(C K)$ and $T_{1}$ were the lowest compared to other treatments in 2011 and 2012, respectively, whereas the soil bulk density of $\mathrm{T}_{5}$ in 2011 and $T_{3}$ in 2012 were higher than other treatments. The soil porosity and field capacity of $T_{5}$ in 2011 and $T_{3}$ in 2012 were lower than other treatments, but those of CK in 2011 and $T_{1}$ in 2012 were higher than other treatments. The $\mathrm{pH}$ values of $\mathrm{T}_{3}$ to $\mathrm{T}_{7}$ were lower than other treatments. These results indicated that the soil bulk densities were increased, whereas the soil porosity, field capacity and values $\mathrm{pH}$ were decreased by $\mathrm{N}$ application at different stages. $\mathrm{N}$ application could increase the $\mathrm{N}$ contents of leaf and stem, whereas less or excess $\mathrm{N}$ application should not significant improve maize yield. Although the soil organic matter and total $\mathrm{N}$ contents of $\mathrm{T}_{3}$ were the highest in both 2011 and 2012, the yield of $T_{4}$ is the highest in both 2011 and 2012. The application amount, period and times of $\mathrm{N}$ fertilizer were important to maize yield.
\end{abstract}

\section{Keywords}

Maize, N Fertilizer Application, Yield, Soil Physical and Chemical Properties, N Content

\footnotetext{
*Both authors contributed equally.
}

"Corresponding author. 


\section{Introduction}

Soil nutrition absorbed by crops can be divided into mobile and immobile [1]. Nitrogen (N) in form of nitrate and water are highly mobile and required in largest amounts by crops. Phosphorus (P) is the most immobile, and potassium (K) is also relatively immobile, both of which are macronutrients required by crops [2]. The contents of $\mathrm{N}, \mathrm{P}$ and $\mathrm{K}$ in agricultural soil are affected by plant growth and yield [3]. Therefore, crop yield is limited by two important mobile resources, including nitrate and water, as well as two immobile resources, $\mathrm{P}$ and $\mathrm{K}$ [4]. In recent years, there was about $60 \%$ of soil nutrition deficiency as a result of long-term agricultural production of existing cultivated land in China, could not meet with the needs of crop yield improvement [5].

Fertilizer plays an important role in crop yield improvement, which increased crops grain yield by 55\% - 57\%, and contributed to $30 \%-31 \%$ of the total grain production [6] [7]. The nitrate $\mathrm{N}$ is easily lost through leaching and denitrification in field soil, whereas the ammonium $\mathrm{N}$ is usually lost through volatilization [8] [9]. China is a big country in consumption of $\mathrm{N}$ fertilizer [10]. The effects of $\mathrm{N}$ fertilizer applications on soil organics matter status and soil physical properties are importance to agricultural sustainability and to increase crop yield [11]. Modern agriculture cultivation, on the contrary, concentrates on supper high grain yield and maximum output, compromising input-use efficiency, therefore may not be sustainable in the long run.

Maize (Zea mays L.) is one of the most important food crops in the world. $\mathrm{N}$ is one of essential nutrient elements for maize growth and development, which use $1 \mathrm{~kg}$ of $\mathrm{N}$ to produce $49 \mathrm{~kg}$ of grain [12]. Although more $\mathrm{N}$ fertilizer has been applied, $\mathrm{N}$ use efficiency has turned lower. The investigation indicated that utilization rate of $\mathrm{N}$ fertilizer was $20 \%$ to $50 \%$ in china [13] [14]. In addition, more and more application of $\mathrm{N}$ fertilizer caused pollution of groundwater and other problems [15] [16]. The extreme of excess application and $\mathrm{N}$ pollution were found in intensive agricultural systems of Western Europe, the United States, and, more recently, China [17]. Therefore, reasonable field managements and appropriate application of $\mathrm{N}$ fertilizer are necessary for the supper high yield of maize.

Many approaches have been practiced for improving $\mathrm{N}$ utilization efficiency in crops, for example, optimal time, rate, and methods of application for matching $\mathrm{N}$ supply with crop demand and the use of specially formulated forms of fertilizer. The results showed that $\mathrm{N}$ application by stages can significantly increase maize grain yield compared to disposable application as sowing manure [18]. Zhang et al. (2014) reported that the regulating $\mathrm{N}$ application (240 kg/ha, divide into 3 equal amounts, each about $80 \mathrm{~kg}$, used as base fertilizer, tillering fertilizer, and booting fertilizer) could increase rice yield while substantially reduced $\mathrm{N}$ leaching losses and improved $\mathrm{N}$ use efficiency in the upper reaches of the Yellow River, China [19]. At present research on application of $\mathrm{N}$ fertilizer roughly includes onetime application technique, basal application and side dressing, the amount of $\mathrm{N}$ fertilizer application, slow-released fertilizers and so on. However, there are few researches on regulating $\mathrm{N}$ application for maize.

In present study, nine $\mathrm{N}$ treatments were carried out to evaluate the effect of different nitrogen applications on soil physical, chemical properties and grain yield production. The objectives are to evaluate the effects of different $\mathrm{N}$ fertilizer application on soil physical and chemical characters and maize yield, and to identify the approach for optimal $\mathrm{N}$ fertilizer application in maize management program.

\section{Materials and Methods}

The experiment was carried out on an experimental farm located in Daguben town $\left(\mathrm{N} 42^{\circ} 28^{\prime}, \mathrm{E} 122^{\circ} 22^{\prime}\right)$, Fuxin city, Liaoning province, China. The hybrid maize variety Zhengdan 958, widely cultivated in northeastern of china, was used in this study. Nine $\mathrm{N}$ fertilizer treatments were arranged in a randomized complete-block design with three replicates, totally including 27 plots. Planting were cultured on 30 ${ }^{\text {th }}$ April, 2011 and on $6^{\text {th }}$ May, 2012. And each plot was $5 \mathrm{~m}$ wide by $8 \mathrm{~m}$ long with 10 rows, row spacing $50 \mathrm{~cm}$.

The nine $\mathrm{N}$ treatments received $\mathrm{T}_{1}$ ( $\mathrm{N} 0 \mathrm{~kg} / \mathrm{ha}$ ), $\mathrm{T}_{2}$ (CK, compound fertilizer $108.75 \mathrm{~kg} / \mathrm{ha}, \mathrm{N} \mathrm{29 \% ,} \mathrm{P} 10 \%$ and $\mathrm{K} 11 \%$ ), $\mathrm{T}_{3}$ (N $138.0 \mathrm{~kg} / \mathrm{ha}, 30 \%$ at sowing and 70\% as side-dressing at jointing stage), $\mathrm{T}_{4}$ ( $\mathrm{N} 241.5 \mathrm{~kg} / \mathrm{ha}, 30 \%$ at sowing and $70 \%$ as side-dressing at jointing stage), $\mathrm{T}_{5}(\mathrm{~N} 345.0 \mathrm{~kg} / \mathrm{ha}, 30 \%$ at sowing and $70 \%$ as sidedressing at jointing stage), $\mathrm{T}_{6}(\mathrm{~N} 241.5 \mathrm{~kg} / \mathrm{ha}, 20 \%$ at sowing, $60 \%$ as side-dressing at jointing stage and $20 \%$ at big flare period), $\mathrm{T}_{7}$ (N $241.5 \mathrm{~kg} / \mathrm{ha}, 30 \%$ at $7 \mathrm{~cm}$ soil layer and $70 \%$ at $15 \mathrm{~cm}$ soil layer), $\mathrm{T}_{8}(\mathrm{~N} 205.2 \mathrm{~kg} / \mathrm{ha}$, Jin zhengda slow-released urea of $\mathrm{N} 35 \%$ at $15 \mathrm{~cm}$ soil layer), $\mathrm{T}_{9}$ (N $241.5 \mathrm{~kg} / \mathrm{ha}$, Jin zhengda slow-released urea of $\mathrm{N} \mathrm{35 \%}$ at $15 \mathrm{~cm}$ soil layer), respectively. In seven treatments from $\mathrm{T}_{3}$ to $\mathrm{T}_{9}$, phosphorus $\left(\mathrm{P}_{2} \mathrm{O}_{5} 103.5 \mathrm{~kg} / \mathrm{ha}\right) \mathrm{and}$ potassium $\left(\mathrm{K}_{2} \mathrm{O} 144 \mathrm{~kg} / \mathrm{ha}\right)$ fertilizers were ploughed into the soil tillage layer in one time as a basal fertilizer. 
Soil samples were collected from a depth of $0-20 \mathrm{~cm}$ on the ridge after harvest in 2011 and 2012. Soil bulk density, soil porosity and field moisture were measured by Wilcox method. Soil organic matter content was measured by potassium dichromate method. The total $\mathrm{N}$ content of soil and plants were calculated by using the Kjeldahl N method, total P content using Mo-Sb colorimetric method, and total K content using flame photometry described by Zhang et al., 2014 [19]. The pH was measured by composite electrode method.

Plant samples were taken at jointing stage and big flare period from the two center rows of each plot. Grain yield were determined by harvesting the two center rows from each plot. One way analysis of variance (ANOVA) at $\alpha=0.05$ probability was conducted to test the significance in different treatments.

\section{Results}

\subsection{Effects of Different N Applications on Soil Physical Properties}

The effects of different $\mathrm{N}$ applications on soil physical properties were list in Table 1 . In 2011, soil bulk density of CK was the lowest, whereas that of $\mathrm{T}_{5}$ was the highest, $23.23 \%$ more than CK. Soil bulk densities under different treatments in 2012 were higher than those in 2011. In 2012, soil bulk density of $\mathrm{T}_{1}$ was the lowest, significantly less than other treatments and $10.44 \%$ less than CK. Soil bulk density of $\mathrm{T}_{3}$ to $\mathrm{T}_{9}$ varied from 1.37 to 1.42 $\mathrm{g} / \mathrm{cm}^{3}$, which of $\mathrm{T}_{3}$ was the highest and $5.97 \%$ higher than $\mathrm{CK}$.

In 2011, different applications of $\mathrm{N}$ fertilizer had no significant on soil moisture. The moisture of $\mathrm{T}_{1}$ was the highest, $10.51 \%$ higher than $\mathrm{CK}$, which of $\mathrm{T}_{3}$ was the lowest, $17.13 \%$ lower than CK. The moisture values in 2012 were higher than those in 2011. The moisture of $\mathrm{T}_{7}$ was the highest, significantly $9.72 \%$ more than CK, while that of $\mathrm{T}_{8}$ was the lowest, and $7.03 \%$ less than $\mathrm{CK}$.

In 2011, field capacity of $\mathrm{T}_{1}$ was the highest, while that of $\mathrm{T}_{3}$ was the lowest, $23.33 \%$ significantly lower than CK. There were no significant different among treatments. In 2012, field capacity of $\mathrm{T}_{1}$ was significantly higher than other treatments. Field capacity of $\mathrm{T}_{4}$ was the lowest, $8.22 \%$ lower than $\mathrm{CK}$, whereas that of $\mathrm{T}_{1}$ was significantly 28.88\% higher than CK. There was no much difference on $\mathrm{pH}$ of different treatments in both 2011 and 2012.

Soil porosity of CK was the highest, while that of $\mathrm{T}_{5}$ was the lowest, $10.7 \%$ less than CK. soil porosities in 2012 were lower than those in 2011 except $T_{1}$. Soil porosity of $T_{1}$ was the highest, 8.9\% higher than CK, whereas that of $\mathrm{T}_{3}$ was the lowest, and $5.72 \%$ lower than $\mathrm{CK}$. Application of $\mathrm{N}$ fertilizer can increase soil bulk

Table 1. Effects of different nitrogen managements on soil physical properties.

\begin{tabular}{|c|c|c|c|c|c|c|}
\hline Year & Treatment & Bulk density $\left(\mathrm{g} / \mathrm{cm}^{3}\right)$ & Moisture (\%) & Field moisture (\%) & Soil porosity (\%) & $\mathrm{pH}$ \\
\hline \multirow{9}{*}{2011} & $\mathrm{~T}_{1}$ & $1.16 \mathrm{a}$ & $16.93 a$ & $31.48 a b$ & $55.55 a$ & $7.78 \mathrm{a}$ \\
\hline & $\mathrm{T}_{2}$ & $0.99 \mathrm{a}$ & $15.32 \mathrm{a}$ & $37.76 a$ & 61.33a & $7.54 \mathrm{a}$ \\
\hline & $\mathrm{T}_{3}$ & $1.17 \mathrm{a}$ & $14.03 a$ & $28.81 \mathrm{~b}$ & $55.23 a$ & 7.39a \\
\hline & $\mathrm{T}_{4}$ & $1.12 \mathrm{a}$ & $15.22 \mathrm{a}$ & 33.72ab & $57.03 a$ & $7.68 \mathrm{a}$ \\
\hline & $\mathrm{T}_{5}$ & $1.22 \mathrm{a}$ & $14.75 a$ & 32.35ab & $53.83 a$ & $7.68 \mathrm{a}$ \\
\hline & $\mathrm{T}_{6}$ & $1.16 \mathrm{a}$ & $15.53 a$ & 31.12ab & $55.71 \mathrm{a}$ & $7.56 \mathrm{a}$ \\
\hline & $\mathrm{T}_{7}$ & $1.15 \mathrm{a}$ & $14.21 \mathrm{a}$ & 34.34ab & $56.02 a$ & 7.73a \\
\hline & $\mathrm{T}_{8}$ & $1.06 \mathrm{a}$ & $15.62 a$ & $32.24 \mathrm{ab}$ & $58.95 a$ & $7.87 \mathrm{a}$ \\
\hline & $\mathrm{T}_{9}$ & 1.19a & $15.31 \mathrm{a}$ & 33.32ab & $54.80 \mathrm{a}$ & $7.84 \mathrm{a}$ \\
\hline \multirow{9}{*}{2012} & $\mathrm{~T}_{1}$ & $1.20 \mathrm{~b}$ & 17.02ab & $36.38 a$ & $54.23 a$ & $7.74 \mathrm{a}$ \\
\hline & $\mathrm{T}_{2}$ & $1.34 \mathrm{a}$ & $17.49 \mathrm{ab}$ & $28.23 b$ & $49.80 \mathrm{~b}$ & 7.51a \\
\hline & $\mathrm{T}_{3}$ & $1.42 \mathrm{a}$ & $16.30 \mathrm{~b}$ & $26.10 \mathrm{~b}$ & $46.95 b$ & $7.94 \mathrm{a}$ \\
\hline & $\mathrm{T}_{4}$ & $1.40 \mathrm{a}$ & 17.16ab & $25.91 b$ & $47.74 \mathrm{~b}$ & 7.51a \\
\hline & $\mathrm{T}_{5}$ & $1.38 \mathrm{a}$ & $17.29 \mathrm{ab}$ & $28.20 \mathrm{~b}$ & $48.55 b$ & $7.67 \mathrm{a}$ \\
\hline & $\mathrm{T}_{6}$ & $1.38 \mathrm{a}$ & $16.71 \mathrm{ab}$ & $27.30 \mathrm{~b}$ & $48.56 b$ & 7.58a \\
\hline & $\mathrm{T}_{7}$ & $1.37 \mathrm{a}$ & 19.19a & $29.43 b$ & $48.60 \mathrm{~b}$ & 7.73a \\
\hline & $\mathrm{T}_{8}$ & $1.40 \mathrm{a}$ & $16.26 \mathrm{~b}$ & $26.78 b$ & $47.75 b$ & 7.98a \\
\hline & $\mathrm{T}_{9}$ & $1.40 \mathrm{a}$ & 17.16ab & $28.55 b$ & $47.75 \mathrm{~b}$ & $7.84 \mathrm{a}$ \\
\hline
\end{tabular}

Note: Different letter stand for the significant levels at 0.05 . 
density and decrease soil porosity.

There were not significant different on $\mathrm{pH}$ values among nine treatments. The values of $\mathrm{T}_{3}$ in 2011 and $\mathrm{CK}$, $\mathrm{T}_{4}$ in 2012 were lower than other treatments, whereas the values of $\mathrm{T}_{8}$ were higher than other treatments in two years.

\subsection{Effects of Different N Applications on Soil Chemical Properties}

The effects of different $\mathrm{N}$ applications on soil chemical properties were shown in Table 2. In 2011, soil organic matter content of $T_{3}$ was the highest and $2.93 \%$ higher than CK, which were significantly higher than $T_{6}, T_{7}, T_{8}$ and $T_{9}$. Soil organic matter content of $T_{8}$ was the lowest, significantly lower than CK. In 2012, soil organic matter content of $\mathrm{T}_{3}$ was also the highest and $3.01 \%$ higher than CK, significantly higher than $\mathrm{T}_{7}, \mathrm{~T}_{8}$ and $\mathrm{T}_{9}$. Soil organic matter content of $\mathrm{T}_{9}$ was the lowest and $8.79 \%$ lower than CK.

In 2011, soil total $\mathrm{N}$ content of $\mathrm{T}_{3}$ was the highest, $13.87 \%$ significantly higher than $\mathrm{CK}$, whereas that of $\mathrm{T}_{1}$ was the lowest, $27.72 \%$ lower than $\mathrm{CK}$. In 2012, soil total $\mathrm{N}$ content of $\mathrm{T}_{3}$ was also the highest, $10.53 \%$ higher than $\mathrm{CK}$, whereas that of $\mathrm{T}_{1}$ was still the lowest, $23.17 \%$ lower than CK. Soil alk-hydr. $\mathrm{N}$ content of $\mathrm{T}_{9}$ was the highest, significantly 79.14\% higher than CK, while that of $\mathrm{T}_{1}$ was the lowest, and $7.29 \%$ lower than CK.

In 2011, soil available $P$ content of $T_{6}$ was the highest, $5.13 \%$ higher than $C K$, whereas that of $T_{4}$ was the lowest, 16.28\% lower than CK. In 2012, soil available P content of $\mathrm{T}_{5}$ was the highest, $33.76 \%$ higher than CK, whereas that of CK was the lowest.

In 2011, soil available $\mathrm{K}$ content of $\mathrm{T}_{8}$ was the highest, significantly $45.4 \%$ higher than CK, while that of $\mathrm{T}_{1}$ was the lowest, significantly $21.2 \%$ lower than CK. In 2012, soil available $K$ content of $T_{5}$ was the highest, significantly $45.39 \%$ higher than CK, whereas that of $\mathrm{T}_{1}$ was still the lowest, significantly $21.19 \%$ lower than CK.

\subsection{Effects of Different N Applications on Dry Matter Accumulation and N, P, K Contents in Plant}

At jointing stage, shoot dry weight of $\mathrm{T}_{3}$ was the highest and significantly $14.77 \%$ higher than $\mathrm{CK}$, whereas that of $\mathrm{T}_{6}$ was the lowest, $17.68 \%$ lower than CK (Table 3). There was no significant influence on alk-hydr. $\mathrm{N}$ contents in leaves. Alk-hydr. $\mathrm{N}$ content in leaf of $\mathrm{CK}$ was the highest, whereas that of $\mathrm{T}_{9}$ was the least. Available $\mathrm{P}$ content in leaf of $\mathrm{T}_{3}$ was the highest, $4.9 \%$ higher than $\mathrm{CK}$, while available $\mathrm{P}$ content in leaf of $\mathrm{T}_{8}$ was the lowest, $13.64 \%$ higher than CK. Available K content of $\mathrm{T}_{3}$ was the highest, $13.64 \%$ higher than $\mathrm{CK}$, whereas that of $\mathrm{T}_{1}$ was the lowest, $15.61 \%$ lower than CK.

At big flare period, shoot dry weight of $\mathrm{T}_{7}$ was the highest, $12.48 \%$ higher than $\mathrm{CK}$, whereas that of $\mathrm{T}_{4}$ was the lowest, significantly 63.64\% lower than CK (Table 4). Alk-hydr. $\mathrm{N}$ content in leaf of $\mathrm{T}_{1}$ was significant $51.98 \%$ lower than CK. Available P content in leaf of $\mathrm{T}_{5}$ was the highest, $67.79 \%$ higher than CK. Available $\mathrm{P}$ content in leaf of $\mathrm{T}_{1}$ was the lowest, significant $39.07 \%$ higher than CK. Available $\mathrm{K}$ content of $\mathrm{T}_{5}$ was the highest, significant $41.29 \%$ higher than CK, while that of $\mathrm{T}_{1}$ was the lowest, $12.48 \%$ lower than CK. Alk-hydr. $\mathrm{N}$ content in stem of CK was the lowest, whereas that of $\mathrm{T}_{5}$ was the highest. Available $\mathrm{P}$ content in stem of $\mathrm{T}_{6}$ was the lowest, $13.61 \%$ higher than $\mathrm{CK}$, whereas available $\mathrm{K}$ content in stem of $\mathrm{T}_{4}$ was the highest, $97.97 \%$ significantly higher than $\mathrm{CK}$, whereas that of $\mathrm{T}_{1}$ was the lowest, $36.11 \%$ lower than $\mathrm{CK}$.

\subsection{Effects of Different N Applications on Maize Yield}

The effects of different $\mathrm{N}$ application on yield were shown on Figure 1. In 2011, the yield of $\mathrm{T}_{4}$ was the largest, $1094.4 \mathrm{~kg} / \mathrm{ha}$ more than CK, whereas that of $\mathrm{T}_{9}$ was the least, $948.9 \mathrm{~kg} / \mathrm{ha}$ less than CK. In 2012, the yield of $\mathrm{T}_{4}$ was still the highest, $224.4 \mathrm{~kg} / \mathrm{ha}$ higher than $\mathrm{CK}$, whereas that of $\mathrm{T}_{1}$ was the least, $1831.2 \mathrm{~kg} / \mathrm{ha}$ less than CK.

\section{Discussion}

Soil bulk density is the ratio of the mass of dry solids to the bulk volume of the soil. The bulk volume includes the volume of the solids and of the pore space. The bulk density reflect the compaction soil, and influence the transform and utilization rate of nutrient in soil directly [20]. In the present study, the soil bulk density of $\mathrm{T}_{1}$ and CK were lower than other treatments in 2011 and 2012, whereas the soil bulk density of $T_{5}$ in 2011 and $T_{3}$ in 2012 were higher than other treatments. Field capacity is the amount soil moisture held in soil after 
Table 2. Effects of different nitrogen applications on soil chemical properties.

\begin{tabular}{ccccccc}
\hline Year & Treatment & $\begin{array}{c}\text { Organic matter } \\
(\mathrm{g} / \mathrm{kg})\end{array}$ & Total N (g/kg) & Alk-hydr. N (mg/kg) & Avail. P (mg/kg) & Avail. K (mg/kg) \\
\hline & $\mathrm{T}_{1}$ & $19.2 \mathrm{abc}$ & $0.41 \mathrm{~b}$ & $44.91 \mathrm{c}$ & $21.34 \mathrm{a}$ & $69.09 \mathrm{~b}$ \\
& $\mathrm{~T}_{2}$ & $19.8 \mathrm{ab}$ & $0.56 \mathrm{ab}$ & $55.28 \mathrm{bc}$ & $23.62 \mathrm{a}$ & $88.40 \mathrm{~b}$ \\
& $\mathrm{~T}_{3}$ & $20.3 \mathrm{a}$ & $0.64 \mathrm{a}$ & $68.52 \mathrm{ab}$ & $25.04 \mathrm{a}$ & $75.59 \mathrm{~b}$ \\
& $\mathrm{~T}_{4}$ & $19.3 \mathrm{abc}$ & $0.44 \mathrm{ab}$ & $48.39 \mathrm{c}$ & $20.42 \mathrm{a}$ & $131.66 \mathrm{a}$ \\
& $\mathrm{T}_{5}$ & $18.6 \mathrm{abc}$ & $0.57 \mathrm{~b}$ & $58.75 \mathrm{~b}$ & $23.80 \mathrm{a}$ & $129.11 \mathrm{a}$ \\
& $\mathrm{T}_{6}$ & $18.2 \mathrm{bc}$ & $0.59 \mathrm{ab}$ & $70.01 \mathrm{a}$ & $25.57 \mathrm{a}$ & $66.98 \mathrm{~b}$ \\
& $\mathrm{~T}_{7}$ & $18.1 \mathrm{bc}$ & $0.59 \mathrm{~b}$ & $59.49 \mathrm{~b}$ & $25.32 \mathrm{a}$ & $73.22 \mathrm{~b}$ \\
& $\mathrm{~T}_{8}$ & $17.9 \mathrm{c}$ & $0.49 \mathrm{~b}$ & $71.96 \mathrm{a}$ & $24.08 \mathrm{a}$ & $133.55 \mathrm{a}$ \\
& $\mathrm{T}_{9}$ & $18.2 \mathrm{bc}$ & $0.64 \mathrm{ab}$ & $76.20 \mathrm{a}$ & $23.75 \mathrm{a}$ & $117.23 \mathrm{~b}$ \\
\hline & $\mathrm{T}_{1}$ & $19.1 \mathrm{a}$ & $0.40 \mathrm{a}$ & $48.72 \mathrm{e}$ & $23.26 \mathrm{a}$ & $88.96 \mathrm{e}$ \\
& $\mathrm{T}_{2}$ & $19.9 \mathrm{ab}$ & $0.52 \mathrm{a}$ & $50.97 \mathrm{e}$ & $20.44 \mathrm{a}$ & $112.88 \mathrm{c}$ \\
& $\mathrm{T}_{3}$ & $20.5 \mathrm{a}$ & $0.58 \mathrm{a}$ & $61.14 \mathrm{~cd}$ & $22.02 \mathrm{a}$ & $147.85 \mathrm{~b}$ \\
& $\mathrm{~T}_{4}$ & $19.2 \mathrm{ab}$ & $0.53 \mathrm{a}$ & $67.37 \mathrm{abc}$ & $22.49 \mathrm{a}$ & $143.92 \mathrm{~b}$ \\
& $\mathrm{~T}_{5}$ & $19.0 \mathrm{ab}$ & $0.48 \mathrm{a}$ & $71.21 \mathrm{ab}$ & $27.34 \mathrm{a}$ & $164.12 \mathrm{a}$ \\
& $\mathrm{T}_{6}$ & $18.5 \mathrm{ab}$ & $0.45 \mathrm{a}$ & $67.37 \mathrm{bcd}$ & $22.45 \mathrm{a}$ & $116.06 \mathrm{c}$ \\
& $\mathrm{T}_{7}$ & $18.3 \mathrm{~b}$ & $0.51 \mathrm{a}$ & $75.39 \mathrm{ab}$ & $24.98 \mathrm{a}$ & $111.39 \mathrm{c}$ \\
& $\mathrm{T}_{8}$ & $17.7 \mathrm{~b}$ & $0.52 \mathrm{a}$ & $54.9 \mathrm{de}$ & $26.82 \mathrm{a}$ & $101.84 \mathrm{~d}$ \\
& $\mathrm{~T}_{9}$ & $18.2 \mathrm{~b}$ & $0.57 \mathrm{a}$ & $75.48 \mathrm{a}$ & $23.35 \mathrm{a}$ & $93.80 \mathrm{de}$ \\
\hline
\end{tabular}

Table 3. Effects of different $\mathrm{N}$ applications on dry matter accumulation and N, P, K contents in plant at joint stage.

\begin{tabular}{|c|c|c|c|c|}
\hline Treatment & Shoot dry weight (g) & $\mathrm{N}(\%)$ & $\mathrm{P}(\%)$ & $\mathrm{K}(\%)$ \\
\hline $\mathrm{T}_{1}$ & $22.89 b c$ & $4.280 \mathrm{a}$ & $0.288 \mathrm{abc}$ & $1.460 \mathrm{~b}$ \\
\hline $\mathrm{T}_{2}$ & $24.64 \mathrm{ab}$ & $5.282 \mathrm{a}$ & $0.330 \mathrm{ab}$ & $1.730 \mathrm{ab}$ \\
\hline $\mathrm{T}_{3}$ & $28.28 \mathrm{a}$ & $4.580 \mathrm{a}$ & $0.347 a$ & $2.003 a$ \\
\hline $\mathrm{T}_{4}$ & $23.55 b c$ & 4.813a & $0.277 \mathrm{bc}$ & 1.563ab \\
\hline $\mathrm{T}_{5}$ & $22.06 \mathrm{bc}$ & $4.726 a$ & $0.303 a b c$ & 1.758ab \\
\hline $\mathrm{T}_{6}$ & $20.29 c$ & 4.319a & $0.342 \mathrm{a}$ & 1.929ab \\
\hline $\mathrm{T}_{7}$ & $20.56 c$ & $4.736 a$ & $0.334 \mathrm{ab}$ & $1.702 \mathrm{ab}$ \\
\hline $\mathrm{T}_{8}$ & $24.85 \mathrm{ab}$ & 4.733a & $0.261 \mathrm{c}$ & $1.957 \mathrm{a}$ \\
\hline $\mathrm{T}_{9}$ & 22.07bc & $4.150 \mathrm{a}$ & $0.298 \mathrm{abc}$ & 1.697ab \\
\hline
\end{tabular}

Table 4. Effects of different $\mathrm{N}$ applications on dry matter accumulation and N, P, K contents in plant at big flare period.

\begin{tabular}{|c|c|c|c|c|c|c|c|}
\hline \multirow{2}{*}{ Treatment } & \multirow{2}{*}{$\begin{array}{l}\text { Shoot dry } \\
\text { weight (g) }\end{array}$} & \multicolumn{3}{|c|}{ Leaf } & \multicolumn{3}{|c|}{ Stem } \\
\hline & & N (\%) & P (\%) & K (\%) & N (\%) & P (\%) & K (\%) \\
\hline $\mathrm{T}_{1}$ & 172.0b & $1.55 \mathrm{e}$ & $0.12 \mathrm{e}$ & $0.84 \mathrm{c}$ & $1.10 \mathrm{e}$ & 0.069a & $0.52 d$ \\
\hline $\mathrm{T}_{2}$ & 210.9ab & $3.22 \mathrm{~d}$ & $0.20 \mathrm{~cd}$ & $0.96 b c$ & $1.03 \mathrm{e}$ & $0.046 a$ & $0.70 \mathrm{~cd}$ \\
\hline $\mathrm{T}_{3}$ & 225.8a & 5.11ab & $0.25 b c$ & 1.21ab & 1.59abc & $0.079 a$ & 0.98abcd \\
\hline $\mathrm{T}_{4}$ & 217.1ab & $5.29 a$ & 0.17de & $0.96 \mathrm{bc}$ & $1.49 \mathrm{bc}$ & $0.081 \mathrm{a}$ & $1.39 a$ \\
\hline $\mathrm{T}_{5}$ & 186.5ab & 4.99ab & $0.33 a$ & $1.35 \mathrm{a}$ & $1.75 \mathrm{ab}$ & $0.074 a$ & 1.00abcd \\
\hline $\mathrm{T}_{6}$ & 186.0ab & 4.91abc & $0.26 \mathrm{abc}$ & 1.26ab & $1.31 \mathrm{de}$ & $0.040 \mathrm{a}$ & 1.27ab \\
\hline $\mathrm{T}_{7}$ & 233.0a & 4.52abc & 0.29ab & $1.30 \mathrm{a}$ & $1.48 \mathrm{bc}$ & $0.045 a$ & 1.29ab \\
\hline $\mathrm{T}_{8}$ & 205.4ab & 4.04bcd & 0.31ab & 1.26ab & 1.57abc & $0.068 \mathrm{a}$ & $1.05 \mathrm{abc}$ \\
\hline $\mathrm{T}_{9}$ & 220.6ab & $3.80 \mathrm{~cd}$ & 0.31ab & 1.14abc & $1.37 \mathrm{~cd}$ & $0.061 \mathrm{a}$ & $0.84 \mathrm{bcd}$ \\
\hline
\end{tabular}

excessive water has drained away and the upper limit of water stage [21]. Soil porosity and assignment can be affected by the bulk volume [22]. The soil porosity and field capacity of $\mathrm{T}_{2}$ in 2011 and $\mathrm{T}_{1}$ in 2012 were higher than other treatments. On the contrary, those of $T_{5}$ in 2011 and $T_{3}$ in 2012 were lower than other treatments. 


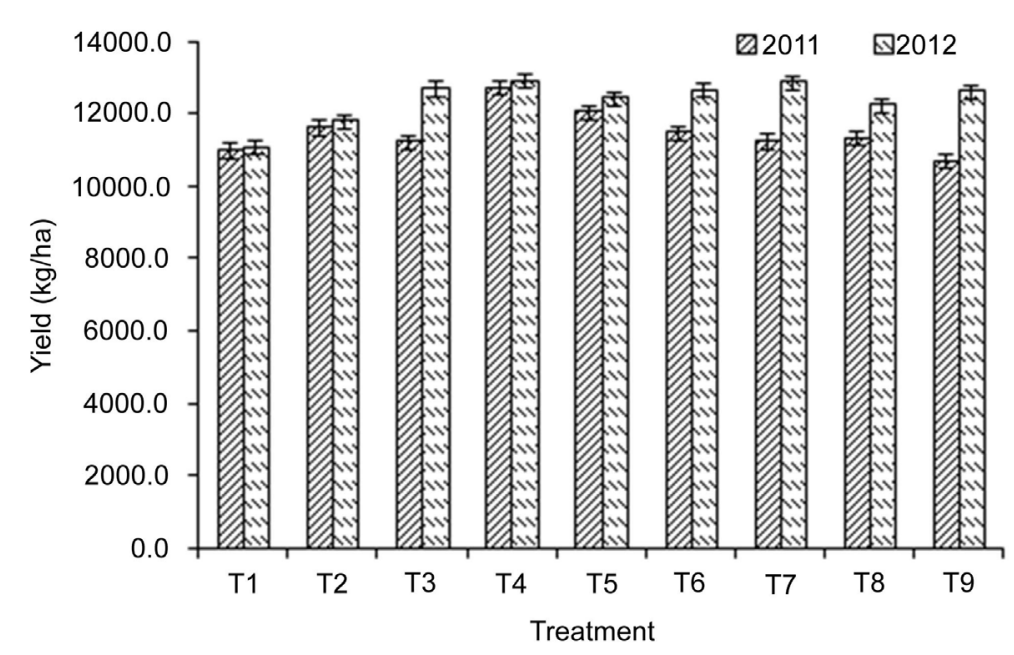

Figure 1. Effects of different $\mathrm{N}$ applications on yield.

Zhong and Shangguan (2014) reported that N-applied treatments increased water consumption in different layer of soil and evapotranspiration, which were significantly higher in $\mathrm{N}$-applied than in non-N treatments [23]. The average soil $\mathrm{pH}$ has decreased 0.5 units due to the excess utilization of $\mathrm{N}$ fertilizer in the past two decades in China [24]. Li et al. (2013) reported that the soil pH declined from 8.76 to 8.56 from 1992 to 2008 during long-term field trials in North region, China [25]. The pH values of T3 to T7 were lower than other treatment in this study. These results indicated that $\mathrm{N}$ application by stages could increase the soil bulk density and decreased the soil $\mathrm{pH}$, while non- $\mathrm{N}$ fertilizer or slow-released urea application should lead to soil harden.

$\mathrm{N}$ uptake and efficiency utilization by maize is very important to $\mathrm{N}$ economy and yield improvement in agricultural production systems [26]. The dry matter production and nutrient accumulation were usually positively correlated with crop grain yield [27]. Meng et al. (2013) reported that the wheat yield increased from 7 - 9 $\mathrm{Mg} \cdot \mathrm{ha}^{-2}$ to $>9 \mathrm{Mg} \cdot \mathrm{ha}^{-2}$ was mainly attributed to increased dry matter and $\mathrm{N}$ accumulation from stem elongation to anthesis period in eleven filed experiments [28]. Ma and Dwyer (1998) indicated that prolonged maintenance of green leaf area for photosynthate and the ability to take up available soil $\mathrm{N}$ during grain filling were characteristics of hybrids maize with greater NUE [29]. Zhang et al. (2013) reported that the contribution of remobilized $\mathrm{N}$ from maize organs to grain showed a trend of blade $>$ stem and sheath $>$ cob $>$ bract according to the maximum value of accumulated $\mathrm{N}$ in organs [30]. In present study, $\mathrm{N}$ contents of shoot were not significant different among nine treatments at joint stage. However, $N$ contents of leaf in $T_{3}$ to $T_{7}$ were significant higher than $T_{1}, T_{2}$, $\mathrm{T}_{7}$ and $\mathrm{T}_{8}$ at big flare period. Specially, $\mathrm{N}$ content of leaf in $\mathrm{T}_{4}$ and $\mathrm{T}_{5}$ was the higher than other treatments. Although the $\mathrm{N}, \mathrm{P}, \mathrm{K}$ contents of leaf and stem in $\mathrm{T}_{5}$ treatment were higher than other treatments, yield of $\mathrm{T}_{5}$ was not the highest. These results indicated that $\mathrm{N}$ application should increase the $\mathrm{N}$ content of leaf and stem, but only reasonable level should increase $\mathrm{N}$ utilization efficiency and significant improve maize yield. These partially attribute to excessive growth caused by overuse fertilizer and vegetative growth consumed more nutrition during growth period in crops.

Soil organic matter content is a major source of system stability in agro ecosystems. Soil total $\mathrm{N}$ and alk-hydr. $\mathrm{N}$ contents are important fertility indexes of soil. Zhou et al. (2013) reported that the soil organic carbon and total nitrogen concentrations had a significant effect on crop yield in the semi-arid Loess Plateau by long-term experimentation [31]. Gong et al., (2013) also indicated that the contribution of soil productivity was significantly correlated with soil organic carbon, total nitrogen, available nitrogen, available phosphorus and available potassium in wheat with long-term soil fertility experiments [32]. The same results were reviewed from the 1970s to the 2000s in the Loess Plateau in China by Wang et al. (2014) [33]. Results showed that changed trends of soil organic matter content under different treatments in two years were similar. Both soil organic matter and total $\mathrm{N}$ content of T3 were the highest in both 2011 and 2012. However, the yield of $\mathrm{T}_{4}$ was higher than other treatments in both two years. Bassoa et al. (2010) indicated that yield response was stronger for $120 \mathrm{~kg} \mathrm{~N} / \mathrm{ha}$ than $60 \mathrm{~kg} \mathrm{~N} / \mathrm{ha}$ and $90 \mathrm{~kg} \mathrm{~N} / \mathrm{ha}$ with the long-term wheat experiment response to $\mathrm{N}$ under rain-fed Mediterranean environments [34]. So these results indicated that separated $\mathrm{N}$ application could significantly increase grain 
yield compared to only one application at sowing, but $\mathrm{N}$ application times should also be controlled. Not only the amount of $\mathrm{N}$ fertilizer application should be taken into account, but also $\mathrm{N}$ application periods and times should be controlled. In our study, control release urea didn't significantly increase maize production and didn't take a significant advantage in improvement of $\mathrm{N}$ use efficiency. But the results of control release urea application in 2012 were better than that in 2011. The advantage of control release urea should be obvious in some years.

\section{Conclusion}

In the present study, nine treatments of $\mathrm{N}$ fertilizer application were carried out to evaluate the variances of soil physical and chemical, the contents of N, P and K in plant and maize grain yield. Results indicated that the soil bulk densities were increased, whereas the soil porosity, field capacity and $\mathrm{pH}$ values were decreased with more $\mathrm{N}$ application. Reasonable $\mathrm{N}$ fertilizer amount (241.5 kg/ha) and application at two stages (30\% at sowing and $70 \%$ at jointing stage) could significant increase $\mathrm{N}$ utilization efficiency and improve maize yield.

\section{Acknowledgements}

The work was financially supported by Key Projects in the National Science \& Technology Pillar Program during the Twelfth Five-Year Plan Period (2011BAD16B12, 2012BAD04B03, 2013BAD07B03), and by the Tianzhu Mountian Scholars Support Plan of Shenyang Agricultural University, and by Program for Liaoning Excellent Talents in University.

\section{References}

[1] Barber, S.A. (1995) Soil Nutrient Bioavailability: A Mechanistic Approach. John Wiley \& Sons, New York.

[2] Marschner, H. (2012) Marschner's Mineral Nutrition of Higher Plants. Elsevier, London.

[3] Havlin, J., Tisdale, S., Nelson, W. and Beaton, J. (2004) Soil Fertility and Fertilizers: An Introduction to Nutrient Management. Prentice Hall, Upper Saddle River.

[4] Lynch, J.P. (2013) Steep, Cheap and Deep: An Ideotype to Optimize Water and N Acquisition by Maize Root Systems. Annals of Botany, 112, 347-357. http://dx.doi.org/10.1093/aob/mcs293

[5] Jin, J.Y. (2012) Changes in the Efficiency of Fertiliser Use in China. Journal of the Science of Food and Agriculture, 92, 1006-1009. http://dx.doi.org/10.1002/jsfa.4700

[6] Ladha, J.K., Pathak, H., Krupnik, T.J., Six, J. and van Kessel, C. (2005) Efficiency of Fertilizer Nitrogen in Cereal Production: Retrospects and Prospects. Advance in Agronomy, 87, 86-156. http://dx.doi.org/10.1016/S0065-2113(05)87003-8

[7] Ye, Y.S., Liang, X.Q., Chen, Y.X., Li, L., Ji, Y.J. and Zhu, C.Y. (2014) Carbon, Nitrogen and Phosphorus Accumulation and Partitioning, and C:N:P Stoichiometry in Late-Season Rice under Different Water and Nitrogen Managements. PLoS ONE, 9, e101776. http://dx.doi.org/10.1371/journal.pone.0101776

[8] Li, S.X., Wang, Z.H., Miao, Y.F. and Li, S.Q. (2014) Soil Organic Nitrogen and Its Contribution to Crop Production. Journal of Integrative Agriculture, 13, 2061-2080. http://dx.doi.org/10.1016/S2095-3119(14)60847-9

[9] Janzen, H.H., Beauchemin, K.A., Bruinsma, Y., Campbell, C.A., Desjardins, R.L., Ellert, B.H. and Smith, E.G. (2003) The Fate of Nitrogen in Agroecosystems: An Illustration Using Canadian Estimates. Nutrient Cycling Agroecosystems, 67, 85-102. http://dx.doi.org/10.1023/A:1025195826663

[10] Ge, J.Z., Li, S.Y., Zhong, X.Y., Yuan, G.Y., Xu, Y., Tian S.Y., Cao, C.G., Zhai, Z.B., Liu, S.Q., Zhan, M. and Zhao, M. (2014) Effects of Nitrogen Application and Film Mulching on Yield Performance Parameters and Nitrogen Use Efficiency of Spring Maize in the Middle Reaches of Yangtze River. Acta Agronomica Sinica, 40, 1081-1092. (In Chinese)

[11] Zhao, J.Y. and Yu, Z.W. (2006) Effects of Nitrogen Rate on Nitrogen Fertilizer Use of Winter Wheat and Content of Soil Nitrate-N under Different Fertility Condition. Acta Ecologica Sinica, 26, 815-822. (In Chinese)

[12] Li, S.X., Wang, Z.H., Miao, Y.F. and Li, S.Q. (2014) Soil Organic Nitrogen and Its Contribution to Crop Production. Journal of Integrative Agriculture, 13, 2061-2080. http://dx.doi.org/10.1016/S2095-3119(14)60847-9

[13] Tilman, D., Cassman, K.G., Matson, P.A., Naylor, R.L. and Polasky, S. (2002) Agricultural Sustainability and Intensive Production Practices. Nature, 418, 671-677. http://dx.doi.org/10.1038/nature01014

[14] Wang, J.J., Ke, F.L., Bai, O. and Huang, R.D. (2008) Effect of Dry Weight Accumulation and Yields of Maize under Different Nitrogen Application. Journal of Shenyang Agricultural University, 39, 392-395. (In Chinese) 
[15] Li, S.Q., Li, S.X. and Li, F.M. (2000) Mineralization and Nitrification of Soil Nitrogen in Calcareous Soil Profile. Journal of Lanzhou University, 36, 98-104. (In Chinese)

[16] Canfield, D.E., Glazer, A.N. and Falkowski, P.G. (2010) The Evolution and Future of Earth’s Nitrogen Cycle. Science, 330, 192-196. http://dx.doi.org/10.1126/science.1186120

[17] Palm, C.A., Machado, P.L.O.A., Mahmood, T., Melillo, J., Murrell, S.T., Nyamangara, J., Scholes, M., Sisworo, E., Olesen, J.E., Pender, J., Stewart, J. and Galloway, J.L. (2004) Societal Responses for Addressing Nitrogen Fertilizer needs: Balancing Food Production and Environmental Concerns. In: Mosier, A.R., Syers, J.K. and Freney, J.R., Eds., Agriculture and the Nitrogen Cycle: Assessing the Impacts of Fertilizer Use on Food Production and the Environment, SCOPE 65, Paris, 71-89.

[18] Yu, H., Yang, G.H. and Wang, Z.J. (2010) Nitrogen Rate and Timing Considerations on Yield and Physiological Parameters of Corn Canopy. Plant Nutrition and Fertilizer Science, 16, 266-273. (In Chinese)

[19] Zhang, A.P., Liu, R.L., Gao, J., Yang, S.Q. and Zhe, C. (2014) Regulating N Application for Rice Yield and Sustainable Eco-Agro Development in the Upper Reaches of Yellow River Basin, China. The Scientific World Journal. (Published Online)

[20] Zhang, J.J., Wang, Y., Fan, T.L., Guo, T.W., Zhao, G., Dang, Y., Wang, L. and Li, S.Z. (2013) Effects of Different Tillage and Fertilization Modes on the Soil Physical and Chemical Properties and Crop Yield under Winter Wheat/Spring Corn Rotation on Dryland of East Gansu, Northwest China. Ying Yong Sheng Tai Xue Bao, 24, 1001-1008. (In Chinese).

[21] Fang, Q., Ma, L., Yu, Q., Malone, R.W., Saseendran, S.A. and Ahuja, L.R. (2008) Modeling Nitrogen and Water Management Effects in a Wheat-Maize Double-Cropping System. Journal of Environmental Quality, 37, $2232-2242$. http://dx.doi.org/10.2134/jeq2007.0601

[22] Arvidsson, J. (1999) Nutrient Uptake and Growth of Barley as Affected by Soil Compaction. Plant and Soil, 208, 9-19. http://dx.doi.org/10.1023/A:1004484518652

[23] Zhong, Y.Q. and Shangguan, Z.P. (2014) Water Consumption Characteristics and Water Use Efficiency of Winter Wheat under Long-Term Nitrogen Fertilization Regimes in Northwest China. PLOS ONE, 9, e98850. http://dx.doi.org/10.1371/journal.pone.0098850

[24] Guo, J.H., Liu, X.J., Zhang, Y., Shen, J.L., Han, W.X., et al. (2010) Significant Acidification in Major Chinese Croplands. Science, 327, 1008-1010. http://dx.doi.org/10.1126/science.1182570

[25] Li, Q., Xu, M.X., Liu, G.B., Zhao, Y.G. and Tuo, D.F. (2013) Cumulative Effects of a 17-Year Chemical Fertilization on the Soil Quality of Cropping System in the Loess Hilly Region, China. Journal of Plant Nutrition and Soil Science, 176, 249-259. http://dx.doi.org/10.1002/jpln.201100395

[26] Cui, Z.L., Zhang, F.S., Miao, Y.X., Sun, Q.P., Li, F., Chen, X.P., Li, J.L., Ye, Y.L., Yang, Z.P. and Zhang, Q. (2008) Soil Nitrate-N Levels Required for High Yield Maize Production in the North China Plain. Nutrient Cycling in Agroecosystems, 82, 187-196. http://dx.doi.org/10.1007/s10705-008-9180-4

[27] Rhoads, F.M. and Stanley, R.L. (1981) Fertilizer Scheduling, Yield, and Nutrient Uptake of Irrigated Corn. Agronomy Journal, 73, 971-974. http://dx.doi.org/10.2134/agronj1981.00021962007300060015X

[28] Meng, Q.F., Yue, S.C., Chen, X.P., Cui, Z.L., Ye, Y.L., Ma, W.Q., Tong, Y.A. and Zhang, F.S. (2013) Understanding Dry Matter and Nitrogen Accumulation with Time-Course for High-Yielding Wheat Production in China. PLoS ONE, 8, e68783. http://dx.doi.org/10.1371/journal.pone.0068783

[29] Ma, B.L. and Dwyer, L.M. (1998) Nitrogen Uptake and Use of Two Contrasting Maize Hybrids Differing in Leaf Senescence. Plant and Soil, 199, 283-291. http://dx.doi.org/10.1023/A:1004397219723

[30] Zhang, J.T., Liu, Y.P., Li X.H., Liang, X.G., Zhou, L.L. and Zhou, S.L. (2013) Dynamic Responses of Nitrogen Accumulation and Remobilization in Summer Maize Organs to Nitrogen Fertilizer. Acta Agronomica Sinica, 39, 506-514. (In Chinese).

[31] Zhou, Z.C., Gan, Z.T., Shangguan, Z.P. and Zhang, F.P. (2013) Effects of Long-Term Repeated Mineral and Organic Fertilizer Applications on Soil Organic Carbon and Total Nitrogen in a Semi-Arid Cropland. European Journal of Agronomy, 45, 20-26. http://dx.doi.org/10.1016/j.eja.2012.11.002

[32] Gong, F.F., Zha, Y., Wu, X.P., Huang, S.M., Xu, M.G., Zhang, H.M., Liu, H.L., Jiang, Z.W., Wang, X.B. and Cai, D.X. (2013) Analysis on Basic Soil Productivity Change of Winter Wheat in Fluvo-Aquic Soil under Long-Term Fertilization. Transactions of the Chinese Society of Agricultural Engineering, 29, 120-129. (In Chinese)

[33] Wang, X.Y., Tong, Y.A., Gao, Y.M., Gao, P.C., Liu, F., Zhao, Z.P. and Pang, Y. (2014) Spatial and Temporal Variations of Crop Fertilization and Soil Fertility in the Loess Plateau in China from the 1970s to the 2000s. PLoS ONE, 9, e112273. http://dx.doi.org/10.1371/journal.pone.0112273

[34] Bassoa, B., Cammarano, D., Troccoli, A., Chen, D.L. and Joe, T. (2010) Long-Term Wheat Response to Nitrogen in a Rained Mediterranean Environment: Field Data and Simulation Analysis. European Journal of Agronomy, 33,132-138. http://dx.doi.org/10.1016/j.eja.2010.04.004 
Scientific Research Publishing (SCIRP) is one of the largest Open Access journal publishers. It is currently publishing more than 200 open access, online, peer-reviewed journals covering a wide range of academic disciplines. SCIRP serves the worldwide academic communities and contributes to the progress and application of science with its publication.

Other selected journals from SCIRP are listed as below. Submit your manuscript to us via either submit@scirp.org or Online Submission Portal.
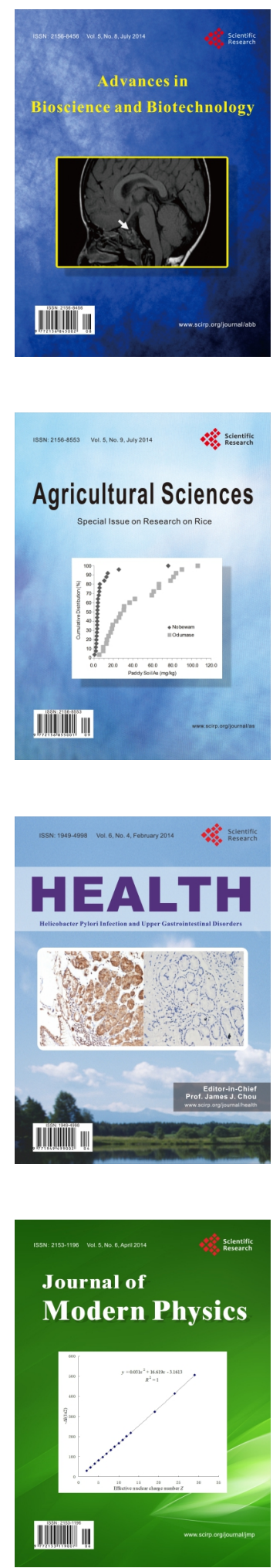
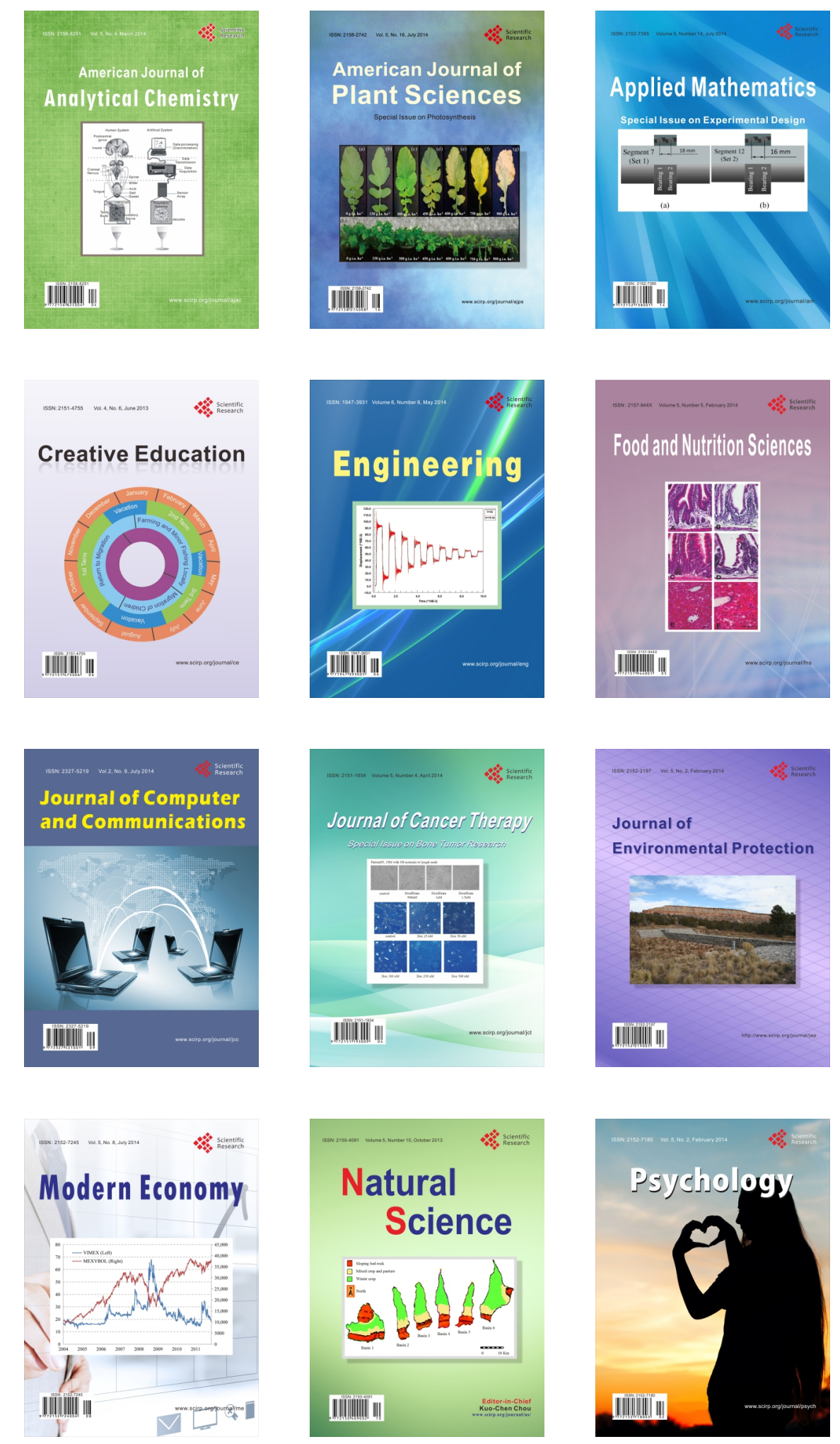